\title{
Paenibacillus soli sp. nov., a xylanolytic bacterium isolated from soil
}

Correspondence

Deok-Chun Yang

dcyang@khu.ac.kr

\author{
Min-Ju Park, ${ }_{1}^{1}$ Ho-Bin Kim, ${ }^{1}$ Dong-Shan An, ${ }^{2}$ Hee-Chan Yang, ${ }^{2}$ \\ Seok-Tae Oh, ${ }^{3}$ Hae-Jung Chung $^{3}$ and Deok-Chun Yang ${ }^{1}$
}

\author{
${ }^{1}$ Department of Oriental Medicinal Material and Processing, College of Life Science, Kyung \\ Hee University, 1 Seocheon-dong, Giheung-gu, Yongin-si, Gyeonggi-do 446-701, \\ Republic of Korea \\ ${ }^{2}$ Department of Biological Sciences, Korea Advanced Institute of Science and Technology, \\ 373-1, Guseong-dong, Yuseong-gu, Daejeon 305-701, Republic of Korea \\ ${ }^{3}$ Department of Culinary Art, Woo Song University, Daejeon 300-718, Republic of Korea
}

\begin{abstract}
Two novel polysaccharide-degrading bacteria (strains $\mathrm{DCY}^{\top} 3^{\top}$ and $\mathrm{DCY} 04$ ) were isolated from a soil sample of a ginseng field in the Republic of Korea and were identified as representing members of the genus Paenibacillus on the basis of phenotypic characteristics and phylogenetic inference based on 16S rRNA gene sequences. Cells of the two isolates were Gram-positive, spore-forming, non-motile, straight rods. Based on DNA-DNA relatedness data, the strains were considered to belong to the same species. The DNA G+C content ranged from 56.6 to $57.0 \mathrm{~mol} \%$. The predominant cellular fatty acid was anteiso- $\mathrm{C}_{15: 0}(63.8-62.8 \%)$. Levels of $16 \mathrm{~S}$ rRNA gene sequence similarity between the two novel isolates and the type strains of recognized Paenibacillus species were 91.4-96.5\%. Strains DCY03 ${ }^{\top}$ and DCY04 could clearly be distinguished from phylogenetically closely related Paenibacillus species on the basis of DNA-DNA relatedness data and phenotypic characteristics. Therefore, on the basis of these data, the two isolates are considered to represent a novel species of the genus Paenibacillus, for which the name Paenibacillus soli sp. nov. is proposed. The type strain is $\mathrm{DCYO3}^{\top}(=\mathrm{KCTC}$ $13010^{\top}=$ LMG $23604^{\top}$ ).
\end{abstract}

Polysaccharide-degrading enzymes such as amylase, cellulase and xylanase are widespread in nature. They can be found in every type of organism, including mammals, plants, algae, moulds, bacteria and phages (Oshima et al., 2002; Sutherland, 1999; Terra \& Ferreira, 1994). For the production of polysaccharases, micro-organisms are usually the most convenient sources, and these can be obtained from various natural environments.

During a study of the bacterial community that produces polysaccharases, a large number of novel bacterial strains were isolated from soil samples from different regions of the Republic of Korea (Kang et al., 2003; An et al., 2005). On the basis of 16S rRNA gene sequence data, two of these isolates, designated strains $\mathrm{DCY} 03^{\mathrm{T}}$ and DCY04, were found to

The GenBank/EMBL/DDBJ accession numbers for the 16S rRNA gene sequence of strains $\mathrm{DCYO3}^{\mathrm{T}}$ and DCY04 are D0309072 and DQ309073, respectively.

Transmission electron micrographs of cells of strains $\mathrm{DCYO}^{\top}$ and DCY04 and an expanded phylogenetic tree based on 16S rRNA gene sequences showing the relationship of Paenibacillus soli sp. nov. to other species of the genus Paenibacillus are available as supplementary material in IJSEM Online. represent members of the genus Paenibacillus and were subjected to polyphasic taxonomic investigation. The results indicated that strains $\mathrm{DCY} 03^{\mathrm{T}}$ and DCY04 are representative of a novel bacterial species.

Strains DCY03 ${ }^{\mathrm{T}}$ and DCY04 were isolated by using the plate technique together with an insoluble chromogenic substrate (Ten et al., 2004). After isolation, strains $\mathrm{DCY}^{\mathrm{T}}{ }^{\mathrm{T}}$ and DCY04 were cultivated via transfer onto R2A agar (Difco) every month. Gram reaction was performed via the nonstaining method as described by Buck (1982). Cell morphology and motility were observed under a Nikon light microscope ( $\times 1000$ magnification), with cells grown on R2A agar for 3 days at $30^{\circ} \mathrm{C}$, and via transmission electron microscopy (JEM-1010) after negative staining with $1 \%(\mathrm{w} / \mathrm{v})$ phosphotungstic acid (see Supplementary Fig. S1 available in IJSEM Online). Growth at different temperatures $\left(4,15,20,30,37,42\right.$ and $\left.50{ }^{\circ} \mathrm{C}\right)$ and various $\mathrm{pH}$ values ( $\mathrm{pH} 5.0-10.0$ at intervals of $0.5 \mathrm{pH}$ units) was assessed after 5 days incubation. Salt tolerance was tested in an R2A broth supplemented with 1-10\% (w/v) $\mathrm{NaCl}$ after 5 days incubation. Growth on nutrient agar, trypticase soy agar (TSA) and MacConkey agar was also evaluated at $30^{\circ} \mathrm{C}$. Growth was estimated by monitoring the $\mathrm{OD}_{600}$. 
Anaerobic growth was performed in serum bottles by adding a thioglycolate $\left(1 \mathrm{~g} \mathrm{l}^{-1}\right)$ to the R2A broth and substituting the upper air layer with nitrogen gas. Substrate utilization as the sole carbon source and some enzyme activities were tested by using the API ZYM, API 50CHB and API 20NE galleries according to the instructions of the manufacturer (bioMérieux). Catalase activity was determined by bubble production with $3 \%(\mathrm{v} / \mathrm{v}) \mathrm{H}_{2} \mathrm{O}_{2}$, and oxidase activity was determined using $1 \%(\mathrm{w} / \mathrm{v})$ tetramethyl $p$-phenylenediamine. Degradation of DNA (using DNA agar from Difco, supplemented with $0.01 \%$ toluidine blue from Merck), casein and starch (Atlas, 1993), lipid (Kouker \& Jaeger, 1987) and xylan (Ten et al., 2004) was also investigated; reactions were read after 5 days.

Purified cell-wall preparations were obtained as described by Schleifer \& Kandler (1972). Amino acids and peptides in cell-wall hydrolysates were analysed by two-dimensional TLC on cellulose plates using solvent systems described by Schleifer \& Kandler (1972). Menaquinone was extracted from cells grown in an R2A broth (Difco) and was analysed as described by Komagata \& Suzuki (1987) using reversedphase HPLC. Cells for analysis of cellular fatty acids were cultivated on TSA agar at $30^{\circ} \mathrm{C}$ for $48 \mathrm{~h}$, then saponified, methylated and extracted according to the protocol of the Sherlock Microbial Identification System (MIDI). The fatty acids analysed via GC (Hewlett Packard 6890) were identified by the Microbial Identification software package (Sasser, 1990). To determine the $\mathrm{G}+\mathrm{C}$ content of the chromosomal DNA, the genomic DNA of the strains was first extracted and purified with the Qiagen Genomic-tip system $100 / \mathrm{G}$; this was then enzymically degraded into nucleosides and the $\mathrm{G}+\mathrm{C}$ content was determined as described by Mesbah et al. (1989) by using reversed-phase HPLC. DNA-DNA hybridization was performed fluorometrically by the method of Ezaki et al. (1989), using photobiotin-labelled DNA probes and micro-dilution wells. Hybridization was performed with five replications for each sample. The highest and lowest values obtained for each sample were excluded, and the remaining three values were used to calculate relatedness values. The DNA hybridization values quoted are the means of these three values.

Extraction of genomic DNA, PCR-mediated amplification of the 16S rRNA gene and sequencing of the purified PCR product were carried out according to Kim et al. (2005). Partial 16S rRNA gene sequences were compiled using SeqMan software; the 16S rRNA gene sequences of the test strains and related taxa (obtained from GenBank) were edited using the BIOEDIT program (Hall, 1999). Multiple alignments were performed by using the CLUSTAL_X program (Thompson et al., 1997). Evolutionary distances were calculated with the Kimura two-parameter model (Kimura, 1983). A phylogenetic tree was constructed by using the neighbour-joining (Saitou \& Nei, 1987) and maximum-parsimony (Fitch, 1971) methods in MEGA 3 (Kumar et al., 2004) with bootstrap values based on 1000 replications (Felsenstein, 1985).
The physiological and biochemical characteristics of strains ${ }_{D C Y 03}{ }^{\mathrm{T}}$ and DCY04 are given in the species description, or are shown in Table 1 together with those of the type strains of related species.

The nearly complete 16S rRNA gene sequences of strains DCY $03^{\mathrm{T}}$ and DCY04 (1486 and $1438 \mathrm{bp}$, respectively) were determined and subjected to comparative analysis. The $16 \mathrm{~S}$ rRNA gene sequence of strain $\mathrm{DCY} 03^{\mathrm{T}}$ showed high similarity (more than $99.0 \%$ ) to that of strain DCY04, and the level of DNA-DNA relatedness between the two strains was $93 \%$. The two novel strains are therefore considered to represent the same species. The phylogenetic tree (Fig. 1) shows that these strains are clustered within the genus Paenibacillus of the class 'Bacilli' (an expanded tree is shown in Supplementary Fig. S2 in IJSEM Online). Levels of

Table 1. Selective phenotypic characteristics of strains $\mathrm{DCY}{ }^{\mathrm{T}}$ and $\mathrm{DCYO} 4$ and the type strains of related species of the genus Paenibacillus

Strains: 1, $\mathrm{DCY}^{\mathrm{T}}{ }^{\mathrm{T}}$; 2, DCY04; 3, P. ehimensis DSM $11029^{\mathrm{T}}$ (Kuroshima et al., 1996); 4, P. elgii KCTC 10016BP ${ }^{\mathrm{T}}$ (Kim et al., 2004); 5, P. chinjuensis DSM $15045^{\mathrm{T}}$ (Yoon et al., 2002); 6, P. koreensis $\mathrm{YC} 00^{\mathrm{T}}$ (Chung et al., 2000); 7, P. naphthalenovorans DSM $14203^{\mathrm{T}}$ (Daane et al., 2002); 8, P. validus DSM $3037^{\mathrm{T}}$ (Heyndrickx et al., 1995). +, Positive reaction; -, negative reaction; W, weakly positive reaction; $\mathrm{V}$, variable reaction; ND, not determined. All species are positive for the production of catalase and acid production from glucose, and negative for $\mathrm{H}_{2} \mathrm{~S}$ production.

\begin{tabular}{|c|c|c|c|c|c|c|c|c|}
\hline Characteristic & 1 & 2 & 3 & 4 & 5 & 6 & 7 & 8 \\
\hline Motility & - & - & + & + & + & + & + & + \\
\hline Oxidase & - & - & + & - & + & + & ND & - \\
\hline$\alpha$-Glucosidase & - & - & + & + & + & + & $\mathrm{V}$ & $\mathrm{W}$ \\
\hline$\beta$-Glucosidase & - & - & ND & + & ND & + & - & + \\
\hline Protease & - & - & + & $\mathrm{ND}$ & + & $\mathrm{ND}$ & - & - \\
\hline Urease & - & - & ND & ND & - & - & + & - \\
\hline Growth at $50^{\circ} \mathrm{C}$ & - & $\mathrm{W}$ & + & - & - & + & - & + \\
\hline $\begin{array}{l}\text { Growth at } 5 \% \\
(\mathrm{w} / \mathrm{v}) \mathrm{NaCl}\end{array}$ & - & - & ND & - & - & + & - & - \\
\hline Production of indole & + & + & ND & + & ND & - & - & - \\
\hline \multicolumn{9}{|l|}{ Fermentation of: } \\
\hline L-Arabinose & + & + & + & - & - & + & - & - \\
\hline Lactose & + & - & $\mathrm{ND}$ & $\mathrm{ND}$ & - & + & - & - \\
\hline Maltose & + & - & ND & + & + & + & + & + \\
\hline D-Raffinose & + & - & ND & $\mathrm{ND}$ & - & + & - & + \\
\hline L-Rhamnose & - & - & $\mathrm{ND}$ & $\mathrm{ND}$ & - & - & - & - \\
\hline D-Xylose & + & + & + & $\mathrm{V}$ & - & - & - & + \\
\hline Glycerol & - & - & $\mathrm{ND}$ & $\mathrm{V}$ & - & ND & - & + \\
\hline Inositol & - & - & $\mathrm{ND}$ & ND & ND & + & - & + \\
\hline Mannitol & - & - & + & + & - & + & + & + \\
\hline Inulin & - & - & $\mathrm{ND}$ & ND & - & - & - & - \\
\hline Salicin & + & - & ND & ND & - & - & - & - \\
\hline $\begin{array}{l}\text { DNA G }+ \text { C } \\
\text { content }(\mathrm{mol} \%)\end{array}$ & 56.6 & 57 & 54.9 & 51.7 & 53 & 54 & 49 & 51.7 \\
\hline
\end{tabular}




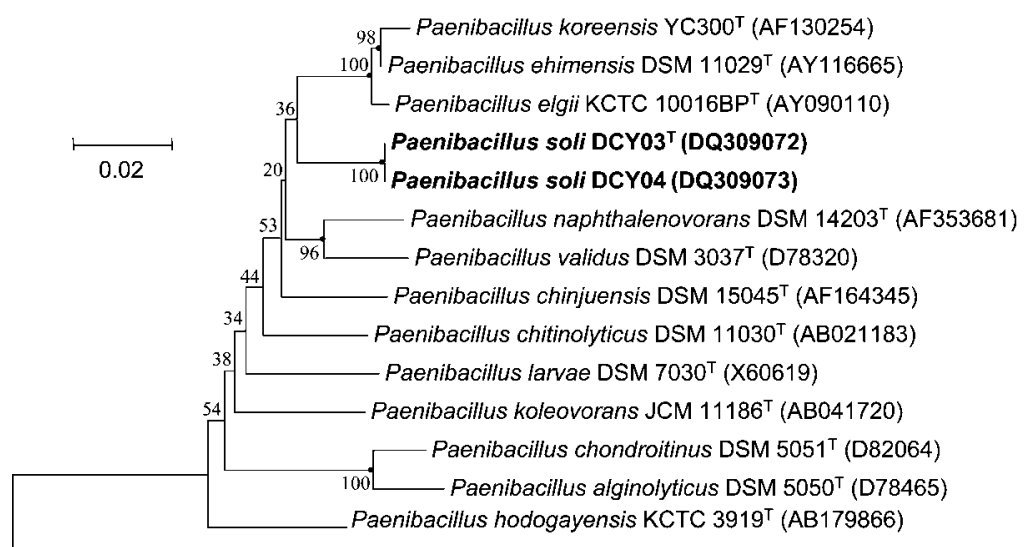

Lactobacillus delbrueckil subsp. lactis DSM $20072^{\top}{ }^{\text {(M58823) }}$
Fig. 1. Neighbour-joining tree based on 16S rRNA gene sequences showing the phylogenetic relationships among members of the genus Paenibacillus. Dots indicate generic branches that were also recovered by using maximum-parsimony algorithms. Bootstrap values are expressed as percentages of 1000 replications at the branch points. Bar, 0.02 substitutions per nucleotide position.
$16 \mathrm{~S}$ rRNA gene sequence similarity between $\mathrm{DCY}^{\mathrm{T}}{ }^{\mathrm{T}}$ and Paenibacillus ehimensis DSM $11029^{\mathrm{T}}$, Paenibacillus elgii KCTC $10016 \mathrm{BP}^{\mathrm{T}}$ and Paenibacillus chinjuensis DSM $15045^{\mathrm{T}}$ were $96.5,96.2$ and $96.1 \%$, respectively. Levels of DNADNA relatedness between strain $\mathrm{DCY} 03^{\mathrm{T}}$ and P. ehimensis DSM $11029^{\mathrm{T}}$, P. elgii KCTC $10016 \mathrm{BP}^{\mathrm{T}}$ and P. chinjuensis DSM $15045^{\mathrm{T}}$ were 30,25 and $22 \%$, respectively. These results suggest that strains $\mathrm{DCY} 03^{\mathrm{T}}$ and DCY04 should be classified as representing a novel species in the genus Paenibacillus, based on the recommendations of Wayne et al.
(1987) and of Stackebrandt \& Goebel (1994) for the delineation of novel species.

The results obtained from chemotaxonomic analyses were in agreement with the results of phylogenetic inference showing that strains $\mathrm{DCY} 3^{\mathrm{T}}$ and DCY04 belong within the genus Paenibacillus. The strains contained MK-7 as the major menaquinone and meso-diaminopimelic acid as the diagnostic diamino acid in the cell-wall peptidoglycan. Whole-cell fatty acid compositions of the two isolates and

Table 2. Cellular fatty acid profiles of strains $D C Y 03^{\top}$ and $D C Y 04$ and other species in the genus Paenibacillus

Strains: 1, DCY03 ${ }^{\mathrm{T}}$; 2, DCY04; 3, P. ehimensis DSM 11029 ${ }^{\mathrm{T}}$ (Kuroshima et al., 1996); 4, P. elgii KCTC 10016BP ${ }^{\mathrm{T}}$ (Kim et al., 2004); 5, P. chinjuensis DSM $15045^{\mathrm{T}}$ (Yoon et al., 2002); 6, P. koreensis $\mathrm{YC}_{000^{\mathrm{T}}}$ (Chung et al., 2000); 7, P. naphthalenovorans DSM 14203 ${ }^{\mathrm{T}}$ (Daane et al., 2002); 8, P. validus DSM $3037^{\mathrm{T}}$ (Heyndrickx et al., 1995). Strains DCY03 ${ }^{\mathrm{T}}$ and DCY04 were cultured on TSA agar at $30^{\circ} \mathrm{C}$ for $48 \mathrm{~h}$. Values are percentages of total fatty acids. Summed features are groups of two or three fatty acids that cannot be separated by GLC with the MIDI system.

\begin{tabular}{|c|c|c|c|c|c|c|c|c|}
\hline Fatty acid & 1 & 2 & 3 & 4 & 5 & 6 & 7 & 8 \\
\hline \multicolumn{9}{|l|}{ Saturated } \\
\hline $\mathrm{C}_{14: 0}$ & 1.7 & 1.7 & 1.0 & 1.9 & 0.8 & 2.5 & 1.2 & 1.7 \\
\hline $\mathrm{C}_{15: 0}$ & 6.9 & 4.9 & 1.2 & 1.2 & 4.5 & & 0.8 & 1.5 \\
\hline $\mathrm{C}_{16: 0}$ & 10.5 & 3.5 & 7.1 & 9.7 & 5.3 & 14.4 & 8.5 & 7.2 \\
\hline $\mathrm{C}_{18: 0}$ & 4.0 & 3.5 & & & & & & 0.3 \\
\hline \multicolumn{9}{|l|}{ Branched } \\
\hline iso- $\mathrm{C}_{14: 0}$ & 2.3 & 3.0 & 1.8 & 2.1 & 2.2 & & 1.6 & 2.3 \\
\hline iso- $\mathrm{C}_{15: 0}$ & 3.6 & 6.6 & 8.1 & 10.6 & 5.0 & 5.3 & 6.0 & 15.1 \\
\hline anteiso- $\mathrm{C}_{15: 0}$ & 57.6 & 64.0 & 52.9 & 54.1 & 66.1 & 51.8 & 43.4 & 52.7 \\
\hline iso- $\mathrm{C}_{16: 0}$ & 5.6 & 6.7 & 8.6 & 6.5 & 7.0 & 5.6 & 12.2 & 6.3 \\
\hline iso- $\mathrm{C}_{17: 0}$ & & & 3.3 & 3.2 & 1.6 & 3.2 & 5.5 & 3.3 \\
\hline anteiso- $\mathrm{C}_{17: 0}$ & 2.7 & 2.5 & 8.0 & 6.2 & 6.1 & 7.9 & 11.9 & 4.6 \\
\hline \multicolumn{9}{|l|}{ Unsaturated } \\
\hline $\mathrm{C}_{16: 1} \omega 7 c$ alcohol & & & 1.2 & & & & 1.4 & 0.9 \\
\hline $\mathrm{C}_{16: 1} \omega 11 c$ & & & 5.2 & 4.5 & & 9.3 & 5.4 & 2.6 \\
\hline $\mathrm{C}_{18: 1} \omega 9 c$ & 2.3 & & & & & & & 0.3 \\
\hline $\begin{array}{l}\text { Summed feature } 4 \\
\qquad\left(\mathrm{C}_{16: 1} \omega 7 c / \text { iso- } \mathrm{C}_{15: 0} 2-\mathrm{OH}\right)\end{array}$ & 1.4 & 1.7 & & & & & & 0.3 \\
\hline $\begin{array}{l}\text { Summed feature } 7 \\
\qquad\left(\mathrm{C}_{18: 1} \omega 7 c / \omega 9 t / \omega 12 t\right)\end{array}$ & 1.5 & 2.0 & & & & & & \\
\hline
\end{tabular}


related species are given in Table 2 . The fatty acid profiles of the two novel strains were similar to those of recognized Paenibacillus species (Shida et al., 1997; Rivas et al., 2005a, b, c; Takeda et al., 2005; Sánchez et al., 2005). The DNA G +C content of the strains was $56.6-57.0 \mathrm{~mol} \%$.

The phenotypic characteristics of strains $\mathrm{DCY}^{\mathrm{T}} 3^{\mathrm{T}}$ and DCY04 were compared with those of some Paenibacillus species that form a coherent phylogenetic cluster. As shown in Table 1, the physiological characteristics of the two novel isolates are different from those of the recognized Paenibacillus species investigated.

Therefore, on the basis of the data presented, strains ${ }_{D C Y} 03^{\mathrm{T}}$ and DCY04 are considered to represent a novel species of the genus Paenibacillus, for which the name Paenibacillus soli sp. nov. is proposed.

\section{Description of Paenibacillus soli sp. nov.}

Paenibacillus soli (so'li. L. neut. gen. n. soli of soil, the source of the organism).

Cells are Gram-positive, aerobic, non-motile and rodshaped, about $0.5-0.6 \mu \mathrm{m}$ in width and $1.1-1.2 \mu \mathrm{m}$ in length. Colonies grown on R2A agar (Difco) for 2 days are smooth, circular and white. Growth occurs at $20-42{ }^{\circ} \mathrm{C}$, $\mathrm{pH} 8-9$ and in the presence of up to $2 \%(\mathrm{w} / \mathrm{v}) \mathrm{NaCl}$. No growth occurs on MacConkey agar. Catalase-positive and oxidase-negative. Positive for aerobic nitrate reduction and indole production. $\mathrm{H}_{2} \mathrm{~S}$ is not produced. Aesculin, starch and xylan are hydrolysed, but gelatin, cellulose, olive oil and DNA are not. Acid is produced from DL-arabinose, ribose, D-xylose, methyl $\beta$-D-xylose, galactose, glucose, fructose, cellobiose, maltose, lactose, melibiose, sucrose, trehalose, melezitose, raffinose, gentiobiose, D-turanose, glycogen, methyl $\alpha$-D-glucoside, 5 -ketogluconate and salicin. Acid is not produced from L-xylose, mannose, sorbose, rhamnose, D-lyxose, D-tagatose, DL-fucose, glycerol, erythritol, adonitol, dulcitol, inositol, mannitol, sorbitol, xylitol, DL-arabitol, methyl $\alpha$-D-mannoside, gluconate, 2 -ketogluconate, $\mathrm{N}$ acetylglucosamine, amygdalin, arbutin or inulin. Arginine dihydrolase, lysine decarboxylase, ornithine decarboxylase and tryptophan deaminase are absent. In assays with the API ZYM system, alkaline phosphatase, esterase (C4), lipase (C14), leucine arylamidase, valine arylamidase, cystine arylamidase, trypsin, $\alpha$-chymotrypsin, $\beta$-glucuronidase, $\alpha$ glucosidase, $\beta$-glucosidase, $N$-acetyl- $\beta$-glucosaminidase, $\alpha$ mannosidase and $\alpha$-fucosidase are absent. The cell-wall peptidoglycan contains meso-diaminopimelic acid. The predominant menaquinone is MK-7. The major fatty acid is anteiso- $\mathrm{C}_{15: 0}$. The DNA $\mathrm{G}+\mathrm{C}$ content is $56.6-57.0 \mathrm{~mol} \%$.

The type strain, DCY03 ${ }^{\mathrm{T}}\left(=\mathrm{KCTC} 13010^{\mathrm{T}}=\mathrm{LMG} 23604^{\mathrm{T}}\right)$, and reference strain, DCY04 (=KCTC 13011=LMG 23602), were isolated from a soil sample from a ginseng field in the Republic of Korea.

\section{Acknowledgements}

This work was supported from the 2006 grant of KOSEF (Functional study of saponin biosynthesis genes by metabolomics in Panax ginseng) and by a BK21 research fellowship from the Ministry of Education and Human Resource Development, Korea.

\section{References}

An, D.-S., Im, W.-T., Yang, H.-C., Kang, M.-S., Kim, K.-K., Jin, L., Kim, M.-K. \& Lee, S.-T. (2005). Cellulomonas terrae sp. nov., a cellulolytic and xylanolytic bacterium isolated from soil. Int J Syst Evol Microbiol 55, 1705-1709.

Atlas, R. M. (1993). Handbook of Microbiological Media, pp. 196, 843. Edited by L. C. Parks. Boca Raton, FL: CRC Press.

Buck, J. D. (1982). Nonstaining ( $\mathrm{KOH})$ method for determination of Gram reactions of marine bacteria. Appl Environ Microbiol 44, 992-993.

Chung, Y. R., Kim, C. H., Hwang, I. \& Chun, J. (2000). Paenibacillus koreensis sp. nov., a new species that produces an iturin-like antifungal compound. Int J Syst Evol Microbiol 50, 1495-1500.

Daane, L. L., Harjono, I., Barns, S. M., Launen, L. A., Palleroni, N. J. \& Haggblom, M. M. (2002). PAH-degradation by Paenibacillus spp. and description of Paenibacillus naphthalenovorans sp. nov., a naphthalene-degrading bacterium from the rhizosphere of salt marsh plants. Int J Syst Evol Microbiol 52, 131-139.

Ezaki, T., Hashimoto, Y. \& Yabuuchi, E. (1989). Fluorometric deoxyribonucleic acid-deoxyribonucleic acid hybridization in microdilution wells as an alternative to membrane filter hybridization in which radioisotopes are used to determine genetic relatedness among bacterial strains. Int J Syst Bacteriol 39, 224-229.

Felsenstein, J. (1985). Confidence limit on phylogenies: an approach using the bootstrap. Evolution 39, 783-791.

Fitch, W. M. (1971). Toward defining the course of evolution: minimum change for a specific tree topology. Syst Zool 20, 406-416.

Hall, T. A. (1999). BIOEDIT: a user-friendly biological sequence alignment editor and analysis program for Windows 95/98/NT. Nucleic Acids Symp Ser 41, 95-98.

Heyndrickx, M., Vandemeulebroecke, K., Scheldeman, P., Hoste, B., Kersters, K., De Vos, P., Logan, N. A., Aziz, A. M., Ali, N. \& Berkeley, R. C. (1995). Paenibacillus (formerly Bacillus) gordonae (Pichinoty et al. 1986) Ash et al. 1994 is a later subjective synonym of Paenibacillus (formerly Bacillus) validus (Nakamura 1984) Ash et al. 1994: emended description of P. validus. Int J Syst Bacteriol 45, 661-669.

Kang, M.-S., Im, W.-T., Ten, L. N. \& Lee, S.-T. (2003). Isolation and diversity of bacteria having extracellular degrading enzymes of xylan and/or amylose and/or cellulose. In Proceedings of the International Meeting of the Federation of Korean Microbiological Societies 2003, abstract B4022, p. 165. Seoul: The Microbiological Society of Korea.

Kim, D. S., Bae, C.-Y., Jeon, J.-J., Chun, S.-J., Oh, H. W., Hong, S. G., Baek, K.-S., Moon, E. Y. \& Bae, K. S. (2004). Paenibacillus elgii sp. nov., with broad antimicrobial activity. Int J Syst Evol Microbiol 54, 2031-2035.

Kim, M. K., Im, W.-T., Ohta, H., Lee, M. \& Lee, S.-T. (2005). Sphingopyxis granuli sp. nov., a $\beta$-glucosidase producing bacterium in the family Sphingomonadaceae in $\alpha-4$ subclass of the Proteobacteria. J Microbiol 43, 152-157.

Kimura, M. (1983). The Neutral Theory of Molecular Evolution. Cambridge: Cambridge University Press.

Komagata, K. \& Suzuki, K. I. (1987). Lipid and cell wall analysis in bacterial systematics. Methods Microbiol 19, 161-207. 
Kouker, G. \& Jaeger, K.-E. (1987). Specific and sensitive plate assay for bacterial lipase. Appl Environ Microbiol 53, 211-213.

Kumar, S., Tamura, K. \& Nei, M. (2004). MEGA3: integrated software for molecular evolutionary genetics analysis and sequence alignment. Brief Bioinform 5, 150-163.

Kuroshima, K.-I., Sakane, T., Takata, R. \& Yokota, A. (1996). Bacillus ehimensis sp. nov. and Bacillus chitinolyticus sp. nov., new chitinolytic members of the genus Bacillus. Int J Syst Bacteriol 46, 76-80.

Mesbah, M., Premachandran, U. \& Whitman, W. B. (1989). Precise measurement of the $\mathrm{G}+\mathrm{C}$ content of deoxyribonucleic acid by highperformance liquid chromatography. Int J Syst Bacteriol 39, 159-167.

Oshima, H., Miyazaki, R., Ohe, Y., Hayashi, H., Kawamura, K. \& Kikuyama, S. (2002). Isolation and sequence of a novel amphibian pancreatic chitinase. Comp Biochem Physiol Part B Biochem Mol Biol 132, 381-388.

Rivas, R., Mateos, P. F., Martínez-Molina, E. \& Velázquez, E. (2005a). Paenibacillus xylanilyticus sp. nov., an airborne xylanolytic bacterium. Int J Syst Evol Microbiol 55, 405-408.

Rivas, R., Mateos, P. F., Martínez-Molina, E. \& Velázquez, E. (2005b). Paenibacillus phyllosphaerae sp. nov., a xylanolytic bacterium isolated from phyllosphere of Phoenix dactylifera. Int J Syst Evol Microbiol 55, 743-746.

Rivas, R., Gutiérrez, C., Abril, A., Mateos, P. F., Martínez-Molina, E., Ventosa, A. \& Velázquez, E. (2005c). Paenibacillus rhizosphaerae sp. nov., isolated from the rhizosphere of Cicer arietinum. Int J Syst Evol Microbiol 55, 1305-1309.

Saitou, N. \& Nei, M. (1987). The neighbor-joining method: a new method for reconstructing phylogenetic trees. Mol Biol Evol 4, 406-425.

Sánchez, M. M., Fritze, D., Blanco, A., Spröer, C., Tindall, B. J., Schumann, P., Kroppenstedt, R. M., Diaz, P. \& Pastor, F. I. J. (2005). Paenibacillus barcinonensis sp. nov., a xylanase-producing bacterium isolated from a rice field in the Ebro River delta. Int J Syst Evol Microbiol 55, 935-939.

Sasser, M. (1990). Identification of Bacteria by Gas Chromatography of Cellular Fatty Acids. MIDI Technical Note 101. Newark, DE: MIDI.
Schleifer, K. H. \& Kandler, O. (1972). Peptidoglycan types of bacterial cell walls and their taxonomic implications. Bacteriol Rev 36, 407-477.

Shida, O., Takagi, H., Kadowaki, K., Nakamura, L. K. \& Komagata, K. (1997). Transfer of Bacillus alginolyticus, Bacillus chondroitinus, Bacillus curdlanolyticus, Bacillus glucanolyticus, Bacillus kobensis, and Bacillus thiaminolyticus to the genus Paenibacillus and emended description of the genus Paenibacillus. Int J Syst Bacteriol 47, 289-298.

Stackebrandt, E. \& Goebel, B. M. (1994). Taxonomic note: a place for DNA-DNA reassociation and $16 \mathrm{~S}$ rRNA sequence analysis in the present species definition in bacteriology. Int J Syst Bacteriol 44, 846-849.

Sutherland, I. W. (1999). Polysaccharases for microbial exopolysaccharides. Carbohydr Polym 38, 319-328.

Takeda, M., Suzuki, I. \& Koizumi, J. (2005). Paenibacillus hodogayensis sp. nov., capable of degrading the polysaccharide produced by Sphaerotilus natans. Int J Syst Evol Microbiol 55, 737-741.

Ten, L. N., Im, W.-T., Kim, M.-K., Kang, M.-S. \& Lee, S.-T. (2004). Development of a plate technique for screening of polysaccharidedegrading microorganisms by using a mixture of insoluble chromogenic substrates. J Microbiol Methods 56, 375-382.

Terra, W. R. \& Ferreira, C. (1994). Insect digestive enzymes: properties, compartmentalization and function. Comp Biochem Physiol Part B Biochem Mol Biol 109, 1-62.

Thompson, J. D., Gibson, T. J., Plewniak, F., Jeanmougin, F. \& Higgins, D. G. (1997). The CLUSTAL_X windows interface: flexible strategies for multiple sequence alignment aided by quality analysis tools. Nucleic Acids Res 24, 4876-4882.

Wayne, L. G., Brenner, D. J., Colwell, R. R., Grimont, P. A. D., Kandler, O., Krichevsky, M. I., Moore, L. H., Moore, W. E. C., Murray, R. G. E. \& other authors (1987). International Committee on Systematic Bacteriology. Report of the ad hoc committee on reconciliation of approaches to bacterial systematics. Int J Syst Bacteriol 37, 463-464.

Yoon, J.-H., Seo, W.-T., Shin, Y. K., Kho, Y. H., Kang, K. H. \& Park, Y.-H (2002). Paenibacillus chinjuensis sp. nov., a novel exopolysaccharideproducing bacterium. Int J Syst Evol Microbiol 52, 415-421. 